\title{
Developing students' critical thinking through constructivist approach on Islamic education in high school in Purwokerto City Central Java Indonesia
}

\author{
Sunhaji, State Islamic Institute of Purwokerto, Indonesia, a.sunhaji@gmail.com \\ Sutrimo Purnomo, State Islamic Institute of Purwokerto, Indonesia, sutrimopurnomo92@gmail.com \\ Sri Winarsih, State Islamic Institute of Purwokerto, Indonesia,winarsihs377@gmail.com
}

\begin{abstract}
This study aims to describe and analyze the concepts and steps of constructivist approach in developing the students' critical thinking in Islamic education. Constructivist approach encourages students to articulate ideas, thoughts and solutions. Thus teaching and learning do not only construct meaning and develop mind, but also deepen the meaning through the expression of ideas. Methodological criticism is often directed at practical implementation of teaching and learning Islamic education which is less varied. This phenomenon is caused by the low performance of teaching and learning Islamic Education. Many teachers of Islamic education have not changed the pattern of teaching. They tend to be rigid, poor methodology, and less varied in using teaching strategies that can improve the interest and enthusiasm of learners. Constructivist approach is able to help improve the quality of learning because this approach invites students to become more dominant, more active to ask questions, discuss, seek ideas to solve problems, and dare to express opinions in accordance with the beliefs they practiced in everyday life. From these results, it can be concluded that critical thinking will be created systematically.
\end{abstract}

Keywords: Constructivist approach, Critical thinking, Islamic religious education Received: $11.11 .2020 \quad$ Accepted: 03.12.2020 $\quad$ Published: 10.01.2021

\section{INTRODUCTION}

One type of thinking is critical thinking skills. According to Mayer (Mayer, 2008), critical thinking always starts with a problem and ends up with a solution or an answer. Moore and Parker assert that critical thinking is careful conclusions as to whether to accept, reject, or suspend judgment against a statement (Moore \& Parker, 1986). In line with Moore and Parker, Parkin explains that critical thinking is reflective and reasonable thinking directed at a decision that will be trusted or do (Salamon \& Parkin, 1992). Constructivist approach gives ample opportunity to the learners to discover, explore, and even express arguments in learning through sharing and discussion in the group.

According to the constructivist approach, knowledge is formed because the student is an active individual who is capable of creating cognitive structures in interaction with the environment. With the help of cognitive structures, students will understand what they have to do. Cognitive Interaction will happen if reality were compiled through cognitive structure created by the students themselves. Cognitive structures always have to be changed and adjusted based on the demands of the environment and the organism that is being changed, the process of adjustment occurs continually through the reconstruction process (Hill \& Willfred, 2009).

The most important thing in the constructivist theory is in the process of learning, where learners should get a priority. Learners should be active in developing their knowledge, rather than teachers or others. They should be responsible for their own results of learning, so that active learning need to be developed. Creativity and active learners will help them to be independent in his cognitive life. Learning is more focused on experimental activities, i.e. adaptation of humanity based upon concrete experiences in the laboratory, discussions with classmates, which is then contemplated for the development of new concepts. Therefore, the accentuation of educating and teaching is not focused on the educator but on the learner. On the other hand, there are some things that get attention from constructivist learning, among others: a) prioritizing to real learning in relevant context, b) prioritizing processes, c) learning in the context of social experience, and d) learning is done in an effort to construct an experience (Abdurrahman, 2004).

In practice, Islamic Education in High School requires a real understanding and practice in their daily lives, as well as more emphasis on the process that is more contextual than just understanding or limited knowledge. In Islamic studies, an integration-interconnection approach is needed with the aim that the 
dichotomy that has been formed by history will be resolved. Understanding Islam is not enough from one approach alone, but requires a complex and comprehensive approach, namely the integrationinterconnection approach (Saftri \& Sa'dudin, 2019). The ultimate goal of general subjects is getting the knowledge and skills to gain worldly life. However, the learning objectives of Islamic education can be directly experienced and felt in the life of society, both regarding theology, shari'ah and morals. Strong criticism often addressed to the learning process of Islamic education in schools because it is considered less effective in shaping the personality and attitude of the Islamic learners. The ineffectiveness of learning Islamic education is not only caused by methodological aspects but also on the purpose, content, learning resources, and learning evaluation system. They are still managed conventionally. An assessment of the purpose and content of learning PAI is more focused on knowledge domain and ignore the affective domain which is actually the cores on the study of religion in schools. This deficiency is then exacerbated by the lack of variety of media development, learning resources, and instructional strategies used by the teachers of Islamic education in schools. What makes it even worse is that the evaluation system is only to measure the depth of students' cognitive domain by using objective test model. The phenomenon is caused by the lower performance of learning Islamic education. The teachers' way of teaching tends to be rigid, poor methodology, and less variation. So, it is not easy to improve the students' spirit and enthusiasm of learning. Apart from a wide range of variables that affect the quality of learning Islamic education in school, the most highlighted aspects as the dominant factor in shaping the learners' behavior is learning patterns that involve the ability of teachers in building the of learners' tradition and spirit. Therefore, this article is specifically aimed at discussing aspects of Islamic education learning methodologies by using constructivist approach as a perspective deemed able to change the orientation of religious learning in the school to become more meaningful.

\section{METHODS}

\section{Types of research}

This research employs a qualitative design to understand and explain the problem through intensive communication with the speaker. The researcher collected data through interviews, observation, and documentation study. Data collected includes: activities undertaken, behavior, perception or opinion, and other aspects related.

Bogdan and Biklen suggested that qualitative researchers pay attention to understand the behavior, views, perceptions, attitudes and others based on the views of the subject (Biklen \& Bogdan, 1982). Therefore, the qualitative researchers collect data through direct contact with the studied subject in which they perform their daily activities.

\section{Location and research subjects}

This study took place at the National High School in the town of Purwokerto in Central Java. The research subjects include a number of Islamic education teachers. In accordance with the characteristics of qualitative research, the sample in this study is "purposive sampling". The results achieved by this sampling are not to seek a generalization, but they can be transferred to the other cases.

To determine the sample, the researcher chose Islamic education teachers who can provide the maximum information about everything related to the constructivist approach to learning Islamic Education. Based on the data or information obtained from a previous sample, the researcher can assign other samples that can be considered to provide more complete and accurate data. Sampling cannot be determined in advance because it is determined by the consideration of the information. S. Nasution explained that the sample unit is considered adequate if it has reached the level of "redundancy", meaning that it is no longer obtained additional meaningful information from the respondents (Nasution, 1988).

\section{Data collection technique}

The data collection technique is very important part of the study. Therefore, the success of a naturalistic study is highly dependent on the accuracy, completeness notes (notes filed) prepared by the researcher. Field notes were compiled through interviews, observation, and documentary studies.

As described in the above research methods, this research is descriptive. To interpret the data that has been collected, it takes a process for comparing the results of these studies with the theories related to the constructivist approach to learning Islamic Education. Processing and interpretation of the data was done by using qualitative analysis. The aim of this qualitative technique is to reveal the constructivist approach in developing the learners' critical thinking skills in Islamic Education. 


\section{RESULTS}

\section{Critical thinking approach through constructivist approach on islamic education in high school in Indonesia}

In the learning of Islamic Education are materials that encourage learners to discover and dig themselves contextually as experienced by learners in their environment. Prior to the data analysis, the researcher outlines the implementation steps of learning done by Islamic education teacher at High School in Indonesia (Costa, 1985). The results of observations on the steps of learning in schools showed that critical thinking domain appeared on the stages of learning through a constructivist approach, as shown in Table 2 .

Table 1. Implementation of the constructivist approach in developing critical thinking in high school

\begin{tabular}{|l|l|l|}
\hline Constructivist Approach & Learning Implementation & Aspects of Critical Thinking \\
\hline Orientation & $\begin{array}{l}\text { Motivating learners of Islamic religious } \\
\text { education and do apersepsi based on } \\
\text { theme from previous lesson }\end{array}$ & Recalling, specific factor \\
\hline Elicitation & $\begin{array}{l}\text { Developing ideas, looking for ideas on } \\
\text { the theme of Islamic religious } \\
\text { education done through brainstorming } \\
\text { and elicitation provided by the teacher }\end{array}$ & $\begin{array}{l}\text { Generalizing and using } \\
\text { abstract information }\end{array}$ \\
\hline Restructuring & $\begin{array}{l}\text { Clarifying ideas with other learners } \\
\text { based on the theme of Islamic } \\
\text { education }\end{array}$ & $\begin{array}{l}\text { Dividing a problem into sub } \\
\text { part }\end{array}$ \\
\hline Application & $\begin{array}{l}\text { Responding to the idea to be applied to } \\
\text { the target using an active strategy. } \\
\text { Learners are divided into several } \\
\text { groups for discussion. }\end{array}$ & Putting together part to \\
form a while \\
\hline Review & $\begin{array}{l}\text { Apply knowledge in daily real-world } \\
\text { situations }\end{array}$ & Feedback and clarification \\
\hline
\end{tabular}

Based on Table 2, we can see a correlation between the implementation of constructivist approach and elements of critical thinking. In addition to the results of learning observation, interviews with some teachers of Islamic education were also conducted. One of the teachers of Islamic education in high school Purwokerto Indonesia said that the constructivist approach greatly assist teachers in forming creative and critical learners. Furthermore, the secondary school teacher revealed:

Islamic Religious Education Learning should be done with the active learning approach, considering that the learning materials of Islamic education dealing with amaliyah, the subject of worship, and muamalah that requires teachers to form students understanding of Islamic Education.

From the result of interview, it can be concluded that the Islamic Religious education teachers should be able to convey the material by using appropriate strategy because the learning material of Islamic Education is not just the domain of cognitive but affective and also psychomotor. Teaching strategies for learning material on the cognitive domain will be different from the affective and psychomotor domain. Cognitive domain is more behaviorist, so that lecturing is a classic method commonly used. Yet, affective and psychomotor domains are more constructivists. At different times, the researcher conducted interviews with Islamic education teacher at high school 2 and high school 3 Purwokerto Indonesia. The Islamic Religious Education teacher at high school 2 tells us that:

Islamic Religious Education learning should encourage students to learn actively either independently or in groups, in order to create the creativity and activity of learners in the study because Islamic education is amaliyah (Interview with the Islamic education teacher from high school 2 Purwokerto city Indonesia).

Islamic Education teachers at high school 3 said that Islamic Education learning formed learners' moral. Moral learning requires varied strategies with emphasis on the learners' performance in learning.

Based on the results of interviews with Islamic education teachers, it can be concluded that the constructivist approach can promote the role of learners to be more active in authentic and situational learning. For examples, learning activities is more interesting and challenging, learners relate more new information to the one that has been previously known, learners are able to reflect on the knowledge being 
studied, and the teachers act more as facilitator to help learners doing construction. Through various characteristics mentioned above, the emergence of critical thinking skills will be easily achieved. With a constructivist approach, students can explore, discover new ideas and knowledge that have been understood from the environment, and encourages students to think critically and creatively in learning. In religious education, there are sources of scripture that encourages learners to perform the activity of thinking. There are verses in the Qur'an that motivate people to think like a sentence la'akum tadakarun, la'alakum ta'qilun, la'alakum tadhabarun, and so forth. Integration and synergy between religious education and the concept of thinking have been widely revealed in the content of Islamic education. Therefore, constructivist approach provides significant contribution to improve the students' critical thinking. Learning that provides more authority to the learners seems more dominant, as well as providing the learners ample scope for arguing, so that the learners' critical level will gradually increase.

Thus, in a constructivist approach the teachers' task is no longer as a teacher but as a mediator and facilitator, which is among others: Provide learning experiences that enable learners to take responsibility in making design, process, and learning activities, so that the lecture teaching model is not the main task of a teacher; Teachers provide the questions or provide activities that stimulate the learners' curiosity, helping them to find, build knowledge, express ideas, opinions, attitudes and communicating their scientific ideas; Provide a means to stimulate learners' thinking and support the students' learning experience; Monitor, evaluate, and indicate whether the learners' thinking is working or not. Teacher shows and questions whether the learners' knowledge can face new related problems. Teachers assist in evaluating the learners' hypothesis and conclusion (Sanjaya, 2011).

Paul Suparno explains the correlation between critical thinking and constructivist approach, among others: a) the purpose of education, according to constructivism, is to encourage or produce the learners' thinking ability in each of the problems found, b) aspects of learning curriculum emphasizes problem solving skills (hand-on problem solving), c)the impact of constructivism encourages teachers to prepare the relationship between facts, and encourage students to analyze, interpret and predict information, and d) learning emphasizes active learning (Suparno, 2001). Costa asserts that critical thinking is related to the use of information, like classify, interpret, analyze, summarize, synthesize, Evaluate, and inform (Costa, 1985). The stages in the learning aim to stimulate the emergence of the learners' critical thinking skills.

\section{Steps of constructivist approach on islamic education in developing for students' critical thinking at high school}

Sharpening critical thinking skills is one of the competencies that are essential in building a valuable learning pillar to build the competence of the nation in improving the quality of educational products. Critical thinking skills is the ability to cultivate the mind to generate new ideas, and to develop critical thinking skills it needs exercises which consider the specific conditions of learners. The main role of teachers, among others, is to develop the attitude and ability of learners that can help to deal with problems in the future in a creative and innovative way.

To solve the problem of students who are lazy to think, it needs an appropriate learning approach in order to achieve learning objectives as expected. Teachers are required to create a learning environment which involves students actively participate in learning activities. Teachers are required to create a learning environment which involves students actively participate in learning activities. The creative and innovative approach to learning that is widely used is the constructivist approach, in which it requires learners to actively participate in class. By using Constructivist approach, it is expected to improve the learners' critical thinking skills and to make it easier to receive learning materials.

Table 2: Steps of learning Islamic education by using constructivist approach

\begin{tabular}{|l|l|l|l|}
\hline Steps & Activity & Teacher's Activity & Learners'Activity \\
\hline Orientation & $\begin{array}{l}\text { Motivating the students } \\
\text { to understand the topics } \\
\text { to be studied }\end{array}$ & $\begin{array}{l}\text { Teacher starts learning } \\
\text { with greetings, praying } \\
\text { and motivate learners } \\
\text { and do apersepsi toward } \\
\text { the material to be given }\end{array}$ & $\begin{array}{l}\text { Learners observe and } \\
\text { introspect from the teacher's } \\
\text { motivation related to the } \\
\text { subject matter }\end{array}$ \\
\hline Elicitation & $\begin{array}{l}\text { Brainstorming to } \\
\text { explore the learners' } \\
\text { ideas, and discuss them } \\
\text { with friends in the } \\
\text { classroom }\end{array}$ & $\begin{array}{l}\text { Leading the class by } \\
\text { conducting } \\
\text { brainstorming about } \\
\text { things related to the } \\
\text { topic of learning by } \\
\text { doing elicitation in the } \\
\text { classroom }\end{array}$ & $\begin{array}{l}\text { Learners do activities, search } \\
\text { and find ideas, and discuss with } \\
\text { their classmates about the } \\
\text { the topic ideas according to }\end{array}$ \\
\hline
\end{tabular}




\begin{tabular}{|l|l|l|l|}
\hline Restructuring & $\begin{array}{l}\text { At this stage, learners } \\
\text { clarify ideas or findings } \\
\text { and contrasting their } \\
\text { ideas with their } \\
\text { classmates in the } \\
\text { classroom by way of } \\
\text { presentation }\end{array}$ & $\begin{array}{l}\text { Teachers provide } \\
\text { opportunities for the } \\
\text { students to present } \\
\text { their findings in class, as } \\
\text { well as discussions with } \\
\text { classmates to find ideas } \\
\text { agreed in the classroom }\end{array}$ & $\begin{array}{l}\text { Do class presentation by } \\
\text { clarifying the ideas in } \\
\text { accordance with the findings in } \\
\text { group discussions }\end{array}$ \\
\hline Application & $\begin{array}{l}\text { Applying the findings/ } \\
\text { ideas or specific } \\
\text { concepts }\end{array}$ & $\begin{array}{l}\text { Provide opportunities } \\
\text { for learners to give an } \\
\text { example of an idea / } \\
\text { notion of thinking on } \\
\text { the situation and } \\
\text { conditions in the society }\end{array}$ & $\begin{array}{l}\text { Learners apply the idea on the } \\
\text { real situation in the community } \\
\text { by showing example }\end{array}$ \\
\hline Review & $\begin{array}{l}\text { To reflect on the } \\
\text { findings in the context } \\
\text { of the real world }\end{array}$ & $\begin{array}{l}\text { Teacher } \\
\text { opportunity to find } \\
\text { ideas that can be } \\
\text { applied in real life }\end{array}$ & $\begin{array}{l}\text { Learners communicate ideas to } \\
\text { be applied in everyday life as } \\
\text { well as assessing conformity } \\
\text { with reality environment }\end{array}$ \\
\hline
\end{tabular}

In addition to the results of documentation studies, the researcher also conducted interviews with teachers of Islamic Education in high school 3 Purwokerto. From the result of interviews, the researcher got information about the steps of constructivist-based learning which in its practice it cannot always run well. There are some Religious Education learning materials that cannot be practiced immediately, such as faith in the Day of Judgment and materials that are more abstract. The constraints identified include the aspects of teachers' creativity. In fact, not all teachers are able and willing to implement various learning strategies including active learning. Some teachers still tend to use conventional methods. Thus, we can say that the dynamics of the constructivist approach to learning Islamic education in high school in Indonesia is very diverse. It is important, however, to remind the teachers to remain using constructivist approach to develop the students' critical thinking skill.

From the results of documentation and interviews, it can be concluded that in order to implement the constructivist approach, the teachers use several methods of learning that encourage students to think critically and creatively, among others: (a) frequently asked questions (questioning) is a strategy or main method in a constructivist approach to measure the extent to which students can recognize the concepts on the topic of the lessons to be learned. Asking in a learning activity is seen as an important activity to stimulate, guide and assess students' thinking skills; (b) in addition to asking, constructivist approach also improves students' knowledge and skills acquired through the investigation until the students find their own answers, and not just remembering the facts. Teachers must always strive to design activities that refer to the activities to find a wide range of materials that will be taught. Inquiry method in the learning process is more students centered. In learning process, a teacher should be able to teach students how they can teach themselves because students are doing more learning activities. In lessons, a teacher should be able to teach how students can teach themselves because students are doing the learning activities. Inquiry method encourages students to find their own answers or knowledge; and (c) learning community or group learning is one of the characteristics of constructivist approach. The way how it works is that by involving a number of students who have been divided into small groups to achieve certain goals together. The development of learning in a group can foster an atmosphere to maintain self-discipline, and an agreement to behave. The group activities will foster collaboration among learners, also with teachers who are openminded. Groups learning can be a healthy competition arena, and can also increase learning motivation of group members.

With a constructivist approach, teachers implement learning in study groups. Learners are divided into groups whose members are heterogeneous. Groups of learners can vary widely in shape in terms of members and quantity. According to Slavin "the number of group members to work effectively consists of four to six people who are heterogeneous" (Slavin, 1995). Learning the concept of communities of learning can take place if there is a two-way communication. Learners are involved in community activities learn to provide information required by the interlocutor and also requested information is also necessary companion study. The concept of community-based learning can take place if there is a two-way communication. Learners who are involved in community-based learning provide information required by their friends as well as asked information needed by their friends. 


\section{DISCUSSION AND CONCLUSIONS}

Critical thinking skills is one of the competencies that are essential in building a valuable learning pillar to develop the competence of the nation in improving the quality of educational products. The ability to think critically is a skill to cultivate the mind to generate new ideas. To develop the critical thinking skills, it needs exercises and considers the unique circumstances of learners. The main role of educators, among others, is to develop the learners' attitude and ability that can help to deal with problems in the future in a creative and innovative way.

Methodologically, Islamic education learning has not properly provided the possibility to offer the critical thinking skills to students. In fact Islam respects thoughts, and do not forbid the tradition of thinking. Dogmatic approach that dominates Islamic learning must be balanced with the use of teaching strategies that more constructivist. Among the ways to develop thinking skills is to provide cognitive 'apprenticeships' in analysis, problem solving, discovery and reasoning through learning. Constructivist approach is one of the subordinates to develop this potential.

\section{REFERENCES}

Abdurrahman, S. (2004). Madrasah dan Pendidikan Anak Bangsa. Raja Grafindo Persada.

Biklen, \& Bogdan. (1982). Qualitative Research for Educcition: An introduction to Theory and Methods. Allyn and Bacon, Inc.

Costa, L. (1985). Teacher Behaviors that Enable Students. ETC Publication.

Hill, F., \& Willfred. (2009). Teori-Teori Pembelajaran. Nusa Media.

Mayer, R. (2008). Learning and Instruction. Ohio.

Moore, B. N., \& Parker, R. (1986). Critical Thinking: Evaluating Claim and Arguments in Every Day Life. Mayfield Publishing Co.

Nasution, S. (1988). Metode Penelitian Naturalistik Kualitatif. Tarsito.

Saftri, E., \& Sa'dudin, I. (2019). Aplikasi Integrasi Interkoneksi Keilmuan di Lembaga Pendidikan Tinggi. Tadrib: Jurnal Pendidikan Agama Islam, 5(1), 122-137. https://doi.org/10.19109/tadrib.v5i1.2731

Salamon, G., \& Parkin, D. N. (1992). Transfer of Learning: Contribution to the International Encyclopedia of Education (2nd ed.). Pergamon Press.

Sanjaya. (2011). Strategi Pembelajaran Beroreintasi Standar Proses Pendidikan. Kencana Prenada Media Group.

Slavin. (1995). Cooperative Learning, Theori, Research and Practice. Allyn and Bacon, Inc.

Suparno, P. (2001). Filsafat Konstruktivisme dalam pendidikan. Kanisius. 